\title{
Ureaplasma-Driven Neuroinflammation in Neonates: Assembling the Puzzle Pieces
}

\author{
Christine Silwedel $^{\mathrm{a}}$ Christian P. Speer ${ }^{\mathrm{a}}$ Christoph Härtel $^{\mathrm{a}}$ Kirsten Glaser ${ }^{\mathrm{a}, \mathrm{b}}$ \\ aUniversity Children's Hospital, University of Wuerzburg, Wuerzburg, Germany; ${ }^{b}$ Department of Women and Child \\ Health, Center for Pediatric Research Leipzig, Division of Neonatology, University of Leipzig, Leipzig, Germany
}

\section{Keywords}

Ureaplasma parvum - Ureaplasma urealyticum • Neonates ·

Preterm infants · Neuroinflammation

\begin{abstract}
Ureaplasma species (spp.) are commonly regarded as lowvirulence colonizers of the genitourinary tract. Intrauterine Ureaplasma infection, however, has been associated with chorioamnionitis and preterm birth. The overall impact of a neonatal Ureaplasma colonization is yet to be understood. High pathogen prevalence and frequent neurological morbidities particularly in immature preterm infants call for an assessment of the significance of Ureaplasma spp. in neonatal neuroinflammation. This narrative review summarizes clinical data, animal studies, and in vitro results to elucidate potential Ureaplasma-associated neurological morbidities as well as underlying mechanisms. Increasing evidence indicates an involvement of Ureaplasma spp. in invasive central nervous system infections, suggesting a meticulous ability of Ureaplasma spp. to interfere with immune defense mechanisms. Ultimately, Ureaplasma spp. should be considered as relevant pathogens in neonatal neuroinflammation.
\end{abstract}

(c) 2020 The Author(s)

Published by S. Karger AG, Basel

karger@karger.com www.karger.com/neo

Karger $\stackrel{\text { ' }}{5}$

GOPEN ACCESS
(C) 2020 The Author(s)

Published by S. Karger AG, Basel

This is an Open Access article licensed under the Creative Commons Attribution-NonCommercial-4.0 International License (CC BY-NC) (http://www.karger.com/Services/OpenAccessLicense), applicable to the online version of the article only. Usage and distribution for commercial purposes requires written permission.

\section{Introduction}

Ureaplasma species (spp.) are some of the smallest self-replicating organisms [1]. Their cultivation can be challenging, and molecular techniques helped improving diagnostic sensitivity and detection rate only recently [2, $3]$. The 2 human spp. Ureaplasma urealyticum (serovar 2 , 4, 5, 7-13) and Ureaplasma parvum (serovar 1, 3, 6, 14) are common colonizers of the adult urogenital tract and often considered of low virulence [1]. In neonates, however, Ureaplasma spp. appear to be clinically relevant pathogens with often underestimated impacts on morbidity and mortality [3].

As many as $80 \%$ of pregnant women can be considered colonized with Ureaplasma spp. in their lower urogenital tract, and vertical transmission during pregnancy occurs frequently $[4,5]$. Ureaplasma spp. were detected in up to $23 \%$ of the umbilical cord blood samples taken from infants born prematurely between 23 and 32 weeks of gestation [6-8]. Prenatal amniotic infection with Ureaplasma spp. has been associated with chorioamnionitis and can contribute to preterm birth $[6,9,10]$. Pre-, peri-, or postnatal transmissions may result in neonatal Ureaplasma infection. This can become apparent either as an acute

Christine Silwedel

University Children's Hospital, University of Wuerzburg Josef-Schneider-St. 2

DE-97080 Wuerzburg (Germany)

Silwedel_C@ukw.de 
invasive infection such as pneumonia and sepsis or may present as long-term inflammation and contribute to chronic morbidities like bronchopulmonary dysplasia [11-14].

Furthermore, Ureaplasma spp. are increasingly considered relevant in neonatal neuroinflammation. The latter may accompany systemic inflammation, for example in the event of Ureaplasma-induced chorioamnionitis [3], but may also be caused by direct Ureaplasma invasion of the central nervous system (CNS): Ureaplasma spp. were detected within the cerebrospinal fluid (CSF) in up to $19 \%$ of the preterm infants $\leq 1,500 \mathrm{~g}$ [8]. This review gathers clinical data as well as evidence from animal and in vitro studies to elucidate the neuroinflammatory potential of Ureaplasma spp.

\section{Ureaplasma-Driven Neonatal Neuroinflammation: In vivo Data}

Within the past 45 years, 35 cases of meningitis caused by Ureaplasma spp. or the related pathogen Mycoplasma hominis were described in neonates, indicating that Ureaplasma spp. are causal pathogens in neonatal CNS infection [15-17]. The most immature preterm infants appear to be at highest risk; however, term neonates can also be affected, and even a first description of Ureaplasma meningitis in an immunocompetent adult patient has recently been published $[16,18]$. Typical clinical symptoms in neonatal Ureaplasma meningitis include sepsis-like conditions, apnea, and seizures, as well as development of internal hydrocephalus, often followed by long-term neurodevelopmental impairment [16]. Chronic courses were described, such as the unique case of an 8-month history of chronic Ureaplasma meningitis in a former preterm infant [17].

Other typical neurological morbidities of prematurity are intraventricular hemorrhage (IVH) and periventricular leukomalacia (PVL). Since inflammation may relevantly contribute to both conditions, a potential causal relationship between Ureaplasma exposure and development of IVH or PVL in preterm infants has been discussed $[1,3,16,19-21]$. Only few and often small clinical studies have addressed this subject so far (Table 1). Two elaborate and comparatively large studies reported a higher risk for development of preterm IVH upon Ureaplasma exposure $[8,22]$ (Table 1$)$. Other studies, however, did not confirm such a correlation $[6,7,23-28]$ (Table 1). Similarly, a significant association between prenatal and postnatal Ureaplasma infection and PVL has not been verified so far $[6-8,22,23,25,26]$ (Table 1). A study addressing long-term neurodevelopmental outcome in preterm infants, however, found intrauterine Ureaplas$m a$ infection to be associated with cerebral palsy and psychomotor delay at the age of 24 months [26].

The presence of Ureaplasma spp. within the CSF is not necessarily accompanied by local inflammation. Single studies reported on Ureaplasma detection within the CSF without an elevation of typical biomarkers of inflammation, such as interleukins (ILs) or tumor necrosis factor- $\alpha$ $[8,29]$. Clinically symptomatic Ureaplasma meningitis, however, is usually accompanied by characteristic CSF findings including pleocytosis, elevated protein, and, typically, decreased glucose levels $[16,17]$.

\section{Ureaplasma-Driven Neonatal Neuroinflammation: Animal Studies}

Animal models addressing Ureaplasma-driven neuroinflammation are scarce. In a mouse model, prenatal Ureaplasma infection provoked abnormal neuronal development with retarded myelination and microglia activation [30]. MRI data suggested disturbed brain growth and maturation upon intra-amniotic Ureaplasma infection in rhesus macaques [31]. Of note, the same primate model found no association between intra-amniotic Ureaplasma exposure and intracerebral elevation of proinflammatory cytokines, including IL- $1 \beta$ and tumor necrosis factor- $\alpha$ [32]. In sheep, chronic intrauterine Ureaplasma exposure resulted in cerebral injury, comprising decreased astrocyte numbers and increased oligodendrocytes [33]. Interestingly, however, this was accompanied by protective preconditioning effects against secondary inflammatory hits [33].

All 3 available animal models described CNS inflammation subsequent to prenatal Ureaplasma infection. However, despite the ability of Ureaplasma spp. to cross the blood-brain barrier (BBB), no Ureaplasma growth was detected in the ovine CSF, and Ureaplasma mRNA was found in only 1 of the 10 primate brains $[32,33]$. To date, there are no animal models representing invasive CNS infection caused by Ureaplasma spp.

\section{Ureaplasma-Driven Neonatal Neuroinflammation: In vitro Data}

Available in vitro data on Ureaplasma-driven neuroinflammation derive from our own cell culture model of Ureaplasma meningitis, using human brain microvascu- 
Table 1. Clinical studies addressing neonatal Ureaplasma exposure and potentially associated neurological morbidities

\begin{tabular}{|c|c|c|c|c|c|c|c|}
\hline Study (year) & Study type & $\begin{array}{l}\text { Infants } \\
\text { total, } n\end{array}$ & $\begin{array}{l}\mathrm{GA}, \\
\text { weeks }\end{array}$ & $\begin{array}{l}\text { Patients } \\
\text { Ureaplasma } \\
\text { POS, } n\end{array}$ & Sample & Methods & $\begin{array}{l}\text { Clinical characteristics } \\
\text { (Ureaplasma NEG vs. Ureaplasma } \\
\text { POS) (significance) }\end{array}$ \\
\hline $\begin{array}{l}\text { Kirchner et al. [28] } \\
\text { (2007) }\end{array}$ & $\begin{array}{l}\text { Single center, } \\
\text { retrospective cohort }\end{array}$ & 48 & $24-32$ & 12 & Amniotic fluid & Culture & IVH ${ }^{\circ} \mathrm{III}-\mathrm{IV}: 3.4$ vs. 12.5 (ns) \\
\hline $\begin{array}{l}\text { Goldenberg et al. [6] } \\
\text { (2008) }\end{array}$ & $\begin{array}{l}\text { Single center, } \\
\text { retrospective cohort }\end{array}$ & 351 & $23-32$ & 61 & Cord blood & Culture & $\begin{array}{l}\text { IVH }{ }^{\circ} \mathrm{III}-\mathrm{IV}: 6.6 \text { vs. } 8.8 \text { (ns) } \\
\text { PVL: } 2.3 \text { vs. } 3.8 \text { (ns) }\end{array}$ \\
\hline \multirow[t]{2}{*}{$\begin{array}{l}\text { Viscardi et al. [8] } \\
\text { (2008) }\end{array}$} & \multirow[t]{2}{*}{$\begin{array}{l}\text { Single center, } \\
\text { prospective cohort }\end{array}$} & \multirow[t]{2}{*}{313} & \multirow[t]{2}{*}{$<33$} & \multirow[t]{2}{*}{74} & Blood & PCR & $\begin{array}{l}\text { IVH all: } 42 \text { vs. } 54(p=0.092) \\
\text { IVH }{ }^{\circ} \text { III-IV: } 12 \text { vs. } 24(p=0.039) \\
\text { PVL: } 7 \text { vs. } 9(\mathrm{~ns})\end{array}$ \\
\hline & & & & & CSF & PCR & $\begin{array}{l}\text { IVH all: } 49 \text { vs. } 44 \text { (ns) } \\
\text { IVH }{ }^{\circ} \text { III-IV: } 16 \text { vs. } 6 \text { (ns) } \\
\text { PVL: } 7 \text { vs. } 3 \text { (ns) }\end{array}$ \\
\hline $\begin{array}{l}\text { Berger et al. [26] } \\
(2009)\end{array}$ & $\begin{array}{l}\text { Single center, } \\
\text { prospective cohort }\end{array}$ & 114 & $23-33$ & 32 & $\begin{array}{l}\text { Amniotic fluid } \\
\text { Amniotic membranes }\end{array}$ & Culture & $\begin{array}{l}\text { IVH: } 22.4 \text { vs. } 25 \text { (ns) } \\
\text { PVL: } 1.5 \text { vs. } 12.5 \text { (ns) } \\
\text { Abnormal } 2 \text { YNDO: } \mathbf{9 . 7} \text { vs. } \mathbf{3 7 . 9} \\
(\boldsymbol{p}=\mathbf{0 . 0 0 3 )}\end{array}$ \\
\hline $\begin{array}{l}\text { Fonseca et al. [27] } \\
\text { (2011) }\end{array}$ & $\begin{array}{l}\text { Single center, } \\
\text { prospective cohort }\end{array}$ & 95 & $\leq 32$ & 12 & Blood & PCR & IVH ${ }^{\circ} \mathrm{III}-\mathrm{IV}: 15.7$ vs. 16.7 (ns) \\
\hline $\begin{array}{l}\text { Kasper et al. [22] } \\
\text { (2011) }\end{array}$ & $\begin{array}{l}\text { Single center, } \\
\text { prospective cohort }\end{array}$ & 257 & $<34$ & 85 & $\begin{array}{l}\text { Amniotic fluid } \\
\text { Placenta } \\
\text { Amniotic membranes }\end{array}$ & $\begin{array}{l}\text { PCR } \\
\text { Culture }\end{array}$ & $\begin{array}{l}\text { IVH: } 8.9 \text { vs. } 18.5(p=0.032) \\
\text { IVH }{ }^{\circ} I I I-I V: 0.0 \text { vs. } 4.9(p= \\
0.013) \\
\text { PVL: } 5.1 \text { vs. } 7.4 \text { (ns) }\end{array}$ \\
\hline $\begin{array}{l}\text { Rodriguez-Trujillo et al. } \\
\text { [23] (2016) }\end{array}$ & $\begin{array}{l}\text { Single center, } \\
\text { prospective cohort }\end{array}$ & 190 & $>24$ & 37 & Amniotic fluid & Culture & 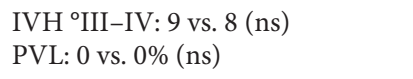 \\
\hline $\begin{array}{l}\text { Cobo et al. [24] } \\
(2017)\end{array}$ & $\begin{array}{l}\text { Single center, } \\
\text { prospective cohort }\end{array}$ & 228 & $22-36$ & 22 & Amniotic fluid & Culture & IVH ${ }^{\circ} \mathrm{III}-\mathrm{IV}: 3$ vs. 4 (ns) \\
\hline $\begin{array}{l}\text { Glaser et al. [7] } \\
(2019)\end{array}$ & $\begin{array}{l}\text { Single center, } \\
\text { prospective cohort }\end{array}$ & 103 & $<30$ & 40 & $\begin{array}{l}\text { Cord blood } \\
\text { Nasopharyngeal swabs }\end{array}$ & $\begin{array}{l}\text { PCR } \\
\text { Culture }\end{array}$ & $\begin{array}{l}\text { IVH }{ }^{\circ I I I-I V: ~} 27 \text { vs. } 28 \text { (ns) } \\
\text { PVL: } 18 \text { vs. } 14 \text { (ns) }\end{array}$ \\
\hline $\begin{array}{l}\text { Takakura et al. [25] } \\
\text { (2019) }\end{array}$ & $\begin{array}{l}\text { Single center, } \\
\text { retrospective cohort }\end{array}$ & 38 & $22-33$ & 5 & Amniotic fluid & Culture & $\begin{array}{l}\text { IVH }{ }^{\circ I I I-I V: ~} 8 \text { vs. } 0 \text { (ns) } \\
\text { PVL: } 8 \text { vs. } 0 \text { (ns) }\end{array}$ \\
\hline
\end{tabular}

Studies with maternal Ureaplasma therapy or without direct comparison between exposed and nonexposed infants were not included. CSF, cerebrospinal fluid; GA, gestational age; IVH, intraventricular hemorrhage; NEG, negative; ns, not significant; POS, positive; PVL, periventricular leukomalacia; 2YNDO, neurodevelopmental outcome after 2 years.

lar endothelial cells (HBMEC), main components of the BBB. Ureaplasma spp. did not evoke classic inflammatory responses in HBMEC $[34,35]$. Some pro-inflammatory mediators were even suppressed upon pathogen exposure, namely, monocyte chemoattractant protein (MCP)-3 and granulocyte colony-stimulating factor (GCSF), as well as important agents in inflammatory cell death, including caspases 1 and 4 [34-36].

Several pro-apoptotic agents, such as caspases 3,7 , and 9, were upregulated in HBMEC upon Ureaplasma exposure, and, ultimately, the rate of cell death increased in cells with pathogen contact [36]. Moreover, Ureaplasma spp. were shown to influence receptors and mediators constituting BBB permeability. Atypical chemokine receptor (ACKR) 3 was elevated in Ureaplasma-exposed HBMEC [37]. Similarly, Ureaplasma spp. increased C-XC chemokine receptor (CXCR) 4 and vascular endothelial growth factor (VEGF) expression in HBMEC $[34,35]$. ACKR3, CXCR4, and VEGF enhancements have all been associated with BBB leakage [38-42]. A negative impact of Ureaplasma spp. on endothelial barrier function was confirmed by continuous monitoring of cell adhesion properties [36].

In HBMEC primed with bacterial LPS, Ureaplasma spp. modulated several LPS-induced immune reactions. LPS-evoked pro-inflammatory cytokine and chemokine 
responses for $\mathrm{C}-\mathrm{X}-\mathrm{C}$ chemokine ligand 5, MCP-1, MCP3, IL-1a, IL-8, G-CSF, and vascular cell adhesion molecule 1 were mitigated upon Ureaplasma exposure [34, 35]. Vice versa, Ureaplasma spp. and LPS showed additive effects regarding mediators increasing BBB permeability, resulting in an intensified elevation of VEGF, intercellular adhesion molecule 1, ACKR3, and CXCR4 [34, $35,37]$.

\section{Discussion}

The neonatal CNS is regarded as an immune-privileged site. Its immune privilege, however, can be undermined once inflammation has been established [43]. In this context, data from clinical and animal studies as well as in vitro results suggest certain key aspects in Ureaplasma-driven neuroinflammation. Ureaplasma exposure distinctly mediates pathways in the CNS that may (i) impair BBB integrity, (ii) mitigate pro-inflammatory immune responses, and (iii) bear an immunomodulatory capacity (Fig. 1).

By employing different mediators and receptors responsible for endothelial barrier function [38-42], Ureaplasma spp. appear to increase BBB permeability [34, 35, 37] (Fig. 1). Ureaplasma-driven apoptosis of HBMEC, as integral components of the $\mathrm{BBB}$, may further compromise BBB integrity [36] (Fig. 1). A similar ability to induce apoptosis in HBMEC has been described for other neuroinvasive pathogens $[44,45]$. BBB breakdown is a key finding in several neuroinflammatory morbidities. It may facilitate pathogen entry into the CNS as well as inflammatory cell influx and thus promote neuroinflammation [46] (Fig. 1). Ureaplasma-driven BBB impairment may therefore represent an important mechanism allowing invasive CNS infection both with Ureaplasma spp. and other pathogens (Fig. 1).

Even if present within the CNS, Ureaplasma spp. do not necessarily evoke classic cytokine and chemokine responses in vivo [29]. In vitro findings similarly indicate absent or even suppressed pro-inflammation [34-36]. In case of infections, cytokines, chemokines, and cell death usually interact to achieve pathogen eradication $[47,48]$. Absent local inflammatory responses in Ureaplasmadriven neuroinflammation may thus impede bacterial elimination, reduce the ability to resolve infections, and promote sustained inflammation [34-36] (Fig. 1). Interestingly, this phenomenon may be limited to Ureaplasma-induced CNS infection. In other (non-immune-privileged) compartments, such as lung, chorioamnion, or blood, Ureaplasma spp. were shown to evoke marked pro-inflammatory immune responses [49-55].

Ureaplasma-driven immunomodulation may be another aspect facilitating secondary infections. In vitro findings of mitigated pro-inflammatory responses in costimulated HBMEC may indicate reduced immune responses in the event of coinfection in vivo [34, 35]. Clinical and animal studies revealed mitigated LPS-induced inflammation in Ureaplasma-colonized fetal sheep and a higher sepsis incidence in Ureaplasma-exposed preterm infants, respectively $[7,56]$. A potentiated enhancement of mediators allowing BBB passage, as seen in co-stimulated cells, may contrarily aggravate barrier impairment and facilitate invasive CNS infections in vivo $[34,35,37]$. As polymicrobial colonization is common in preterm infants, Ureaplasma-driven immunomodulation in the event of coinfection may be of particular clinical relevance.

Some inflammatory mediators appear to exert additional neuroprotective and neuroregenerative effects. In animal models, MCP-1 increased brain ischemia tolerance and G-CSF proved beneficial in neonatal hypoxemia-ischemia $[57,58]$. Ureaplasma-induced attenuation of these mediators in vitro may therefore indicate impaired brain resilience and increased CNS vulnerability to secondary injurious events in vivo. Altogether, this may not only aggravate the sequelae of Ureaplasma CNS infection, but may also facilitate other neurological morbidities of prematurity (Fig. 1).

Only few clinical studies address the potential association between Ureaplasma exposure and development of IVH and PVL. Results are contradictory, and several studies are limited by small numbers (Table 1). Moreover, a certain selection bias has to be presumed, since invasive diagnostic measures are primarily applied to sicker patients. Most authors furthermore did not distinguish between Ureaplasma urealyticum and Ureaplasma parvum, although no difference in outcome was found in the 1 study comparing both spp. [8]. IVH and PVL are both commonly associated with severe long-term sequelae and are therefore of considerable clinical relevance. Scarce data call for large clinical studies to elucidate the role of Ureaplasma spp. in these morbidities.

Apart from a direct impact of local Ureaplasma CNS infection, brain injury may also be generated by Ureaplasma-driven systemic inflammation initiated elsewhere (Fig. 1). Animal models demonstrated brain-derived inflammatory responses upon peripheral cytokine exposure and profound neurodegeneration caused by systemic inflammation $[59,60]$. Increased levels of pro-inflam- 


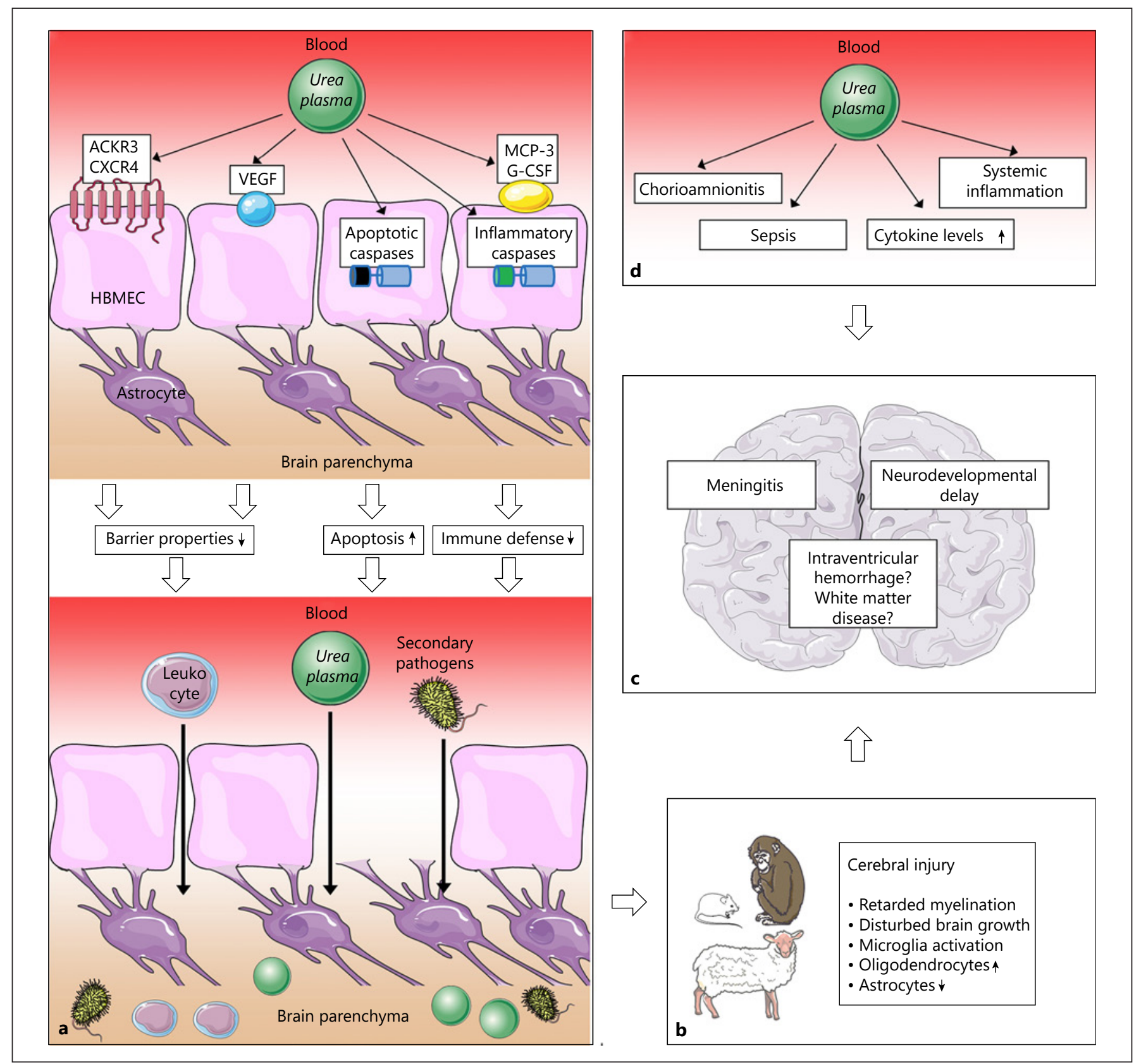

Fig. 1. Presumed cascades and pathomechanisms in Ureaplasmadriven neuroinflammation. a In vitro results indicate that Ureaplasma spp. may increase BBB permeability via employment of ACKR3, CXCR4, and VEGF. Apoptosis of HBMEC may additionally impair barrier function. Mitigation of the inflammatory mediators MCP-3 and G-CSF as well as downregulation of inflammatory caspases may hamper pathogen elimination. All factors may ultimately facilitate influx of inflammatory cells, Ureaplasma spp., and other pathogens into the CNS. b Animal data confirm Ureaplasma-associated neuronal impairment and cerebral injury. c Ul- timate consequence may be acute and chronic neuroinflammation, as seen in clinical studies. d Ureaplasma-driven systemic inflammation may contribute to CNS affection. Illustrations: https:// smart.servier.com/.spp., species; BBB, blood-brain barrier; ACKR, atypical chemokine receptor; $\mathrm{CXCR}, \mathrm{C}-\mathrm{X}-\mathrm{C}$ chemokine receptor; VEGF, vascular endothelial growth factor; HBMEC, human brain microvascular endothelial cells; MCP, monocyte chemoattractant protein; G-CSF, granulocyte colony-stimulating factor; CNS, central nervous system. 
matory cytokines were furthermore able to evoke $\mathrm{BBB}$ leakage in vitro [61]. In preterm infants, development of IVH or white matter disease have been associated with chorioamnionitis or elevated amniotic fluid ILs [19-21]. Elevated amniotic fluid IL levels in chronic Ureaplasma infected sheep, distinct pro-inflammatory responses in human monocytes, and the association between Ureaplasma spp. and chorioamnionitis may therefore indicate additional indirect pathways of Ureaplasma-driven neuroinflammation [6, 8-10, 52-55, 62, 63]. Pre-, peri-, or postnatal Ureaplasma exposure may activate fetal and neonatal inflammatory cascades, leading to systemic inflammation. This may, ultimately, cause CNS inflammation and brain injury in the affected infant even without the presence of Ureaplasma spp. within the CNS (Fig. 1). This hypothesis is underlined by an ovine model of chronic intrauterine Ureaplasma infection, where cerebral inflammatory responses were registered, but not accompanied by cultural detection of Ureaplasma spp. in CSF [33]. In fact, studies found IVH development in preterm infants associated with in utero Ureaplasma exposure [22] as well as with Ureaplasma detection in serum, but not in CSF [8].

Of note, animal data demonstrated not only injurious but also protective effects of systemic fetal Ureaplasma exposure, preventing brain injury upon a second inflammatory hit [33]. This "preconditioning" could be explained by a phenomenon similar to a condition called "endotoxin tolerance," describing a transiently refractory immune state following inflammation [64]. Assuming such Ureaplasma-driven endotoxin tolerance, systemic Ureaplasma infection may therefore prevent local CNS inflammation to some extent: systemic inflammation initiated by Ureaplasma spp. might cause a subsequent refractory immune state. Even in case of inflammation-induced BBB impairment, allowing influx of Ureaplasma and inflammatory cells into the CNS, local interactions between Ureaplasma spp. and preexposed immune cells would be mitigated. In fact, this phenomenon might explain cases of Ureaplasma presence within the CNS without relevant inflammatory responses [8, 29]. Dual effects exerted by Ureaplasma spp. may furthermore contribute to discrepant clinical data regarding an association with, for example, IVH and PVL (Table 1). Pathogen virulence, host immune response, and contributing risk factors such as polymicrobial interaction and the duration of infection might be critical determinants shaping Ureaplasma effects [3].

Increasing evidence for Ureaplasma-driven neonatal neuroinflammation raises the consecutive question of potential therapeutic approaches. Treatment standards of neonatal Ureaplasma infection in general are poorly defined, and therapy of Ureaplasma-driven CNS inflammation in particular is hampered by poor CNS penetration of well-established antibiotics like macrolides and clindamycin. Chloramphenicol as well as tetracyclines and quinolones have successfully been used for treatment of Ureaplasma meningitis in neonates, although contraindications and side effects have to be considered $[16,17]$. In general, however, a postnatal therapy cannot fully intercept inflammatory processes deriving from intrauterine Ureaplasma exposure and might therefore not sufficiently prevent associated neonatal morbidities. In fact, a significantly increased rate of IVH was described in Ureaplasma-colonized preterm infants despite neonatal macrolide therapy [65]. Questions remaining to be determined therefore include the appropriate timing of antimicrobial therapy, the choice of antibiotics, duration and dosage of treatment, and the differentiation between colonization and infection [3]. Furthermore, antibiotic resistances as well as potential adverse effects have to be taken into account. Maternal erythromycin therapy, for example, has been associated with higher rates of infantile cerebral palsy, indicating potential long-term risks of treatment during pregnancy [66].

\section{Conclusion}

In vivo and in vitro data indicate a neuroinflammatory capacity of Ureaplasma spp. By employing a variety of mechanisms, Ureaplasma spp. appear to weaken different host immune defense strategies. Ureaplasma-driven BBB breakdown may facilitate CNS invasion, and attenuated immune reactions may impede pathogen eradication and allow chronic infections. Immunomodulation may aggravate these effects in the event of coinfections. Brain injury may furthermore derive from neonatal systemic Ureaplasma infection and sustained systemic inflammatory response.

Against the background of high prevalence of Ureaplasma spp. particularly in very immature preterm infants and persistently high rates of CNS morbidity in this cohort, the complex interplay of mechanisms exerted or induced by Ureaplasma spp. ought to attract notice to a considerable clinical relevance of Ureaplasma-driven neuroinflammation in neonates. Its full impact is likely to still be underestimated. 


\section{Conflict of Interest Statement}

The authors have no conflicts of interest to declare.

\section{Author Contributions}

C.S. was responsible for conception, design, and drafting of this work. C.P.S., C.H., and K.G. were involved in conception and critical revision.

\section{Funding Sources}

The authors did not receive any funding.

\section{References}

1 Waites KB, Katz B, Schelonka RL. Mycoplasmas and Ureaplasmas as neonatal pathogens. Clin Microbiol Rev. 2005;18(4):757-89.

2 Oh KJ, Lee SE, Jung H, Kim G, Romero R, Yoon $\mathrm{BH}$. Detection of Ureaplasmas by the polymerase chain reaction in the amniotic fluid of patients with cervical insufficiency. J Perinat Med. 2010;38(3):261-8.

3 Silwedel C, Speer CP, Glaser K. Ureaplasmaassociated prenatal, perinatal, and neonatal morbidities. Expert Rev Clin Immunol. 2017; 13(11):1073-87.

4 Iwasaka T, Wada T, Kidera Y, Sugimori H. Hormonal status and mycoplasma colonization in the female genital tract. Obstet Gynecol. 1986;68(2):263-6.

5 Rittenschober-Böhm J, Waldhoer T, Schulz SM, Stihsen B, Pimpel B, Goeral K, et al. First trimester vaginal Ureaplasma biovar colonization and preterm birth: results of a prospective multicenter study. Neonatology. 2018; 113(1):1-6.

6 Goldenberg RL, Andrews WW, Goepfert AR, Faye-Petersen O, Cliver SP, Carlo WA, et al. The alabama preterm birth study: umbilical cord blood Ureaplasma urealyticum and mycoplasma hominis cultures in very preterm newborn infants. Am J Obstet Gynecol. 2008; 198(1):43-5.

7 Glaser K, Gradzka-Luczewska A, Szymankiewicz-Breborowicz M, Kawczynska-Leda N, Henrich B, Waaga-Gasser AM, et al. Perinatal Ureaplasma exposure is associated with increased risk of late onset sepsis and imbalanced inflammation in preterm infants and may add to lung injury. Front Cell Infect Microbiol. 2019.

8 Viscardi RM, Hashmi N, Gross GW, Sun CC, Rodriguez A, Fairchild KD. Incidence of invasive Ureaplasma in VLBW infants: relationship to severe intraventricular hemorrhage. J Perinatol. 2008;28(11):759-65.

9 Sweeney EL, Dando SJ, Kallapur SG, Knox CL. The human Ureaplasma species as causative agents of chorioamnionitis. Clin Microbiol Rev. 2017;30(1):349-79.

10 Sweeney EL, Kallapur SG, Gisslen T, Lambers DS, Chougnet CA, Stephenson SA, et al. Placental infection with Ureaplasma species is associated with histologic chorioamnionitis and adverse outcomes in moderately preterm and late-preterm infants. J Infect Dis. 2016; 213(8):1340-7.
11 Viscardi RM. Ureaplasma species: role in neonatal morbidities and outcomes. Arch Dis Child Fetal Neonatal Ed. 2014;99(1):F87-92.

12 Groneck P, Goetze-Speer B, Speer CP. Inflammatory bronchopulmonary response of preterm infants with microbial colonisation of the airways at birth. Arch Dis Child Fetal Neonatal Ed. 1996;74(1):F51-5.

13 Speer CP. Inflammation and bronchopulmonary dysplasia: a continuing story. Semin Fetal Neonatal Med. 2006;11(5):354-62.

14 Speer CP. Chorioamnionitis, postnatal factors and proinflammatory response in the pathogenetic sequence of bronchopulmonary dysplasia. Neonatology. 2009;95(4):353-61.

15 Keus AMJMH, Peeters DD, Bekker VV, Veldkamp KEKE, Lambregts MM, Bolt-Wieringa $\mathrm{JJ}$, et al. Neonatal meningitis and subdural empyema caused by an unusual pathogen. $\mathrm{Pe}-$ diatr Infect Dis J. 2019;38(12):e329-e31.

16 Glaser K, Speer CP. Neonatal CNS infection and inflammation caused by Ureaplasma species: rare or relevant? Expert Rev Anti Infect Ther. 2015;13(2):233-48.

17 Glaser K, Wohlleben M, Speer CP. An 8 -month history of meningitis in an extremely low birth weight infant? - long-lasting Infection with Ureaplasma parvum. Z Geburtshilfe Neonatol. 2015;219(1):52-6.

18 Pailhories H, Chenouard R, Eveillard M, Kempf M, Pereyre S, Bebear C, et al. A case of Ureaplasma parvum meningitis in an adult after transphenoidal ablation of craniopharyngioma. Int J Infect Dis. 2019;84:5-7.

19 Yoon BH, Jun JK, Romero R, Park KH, Gomez R, Choi JH, et al. Amniotic fluid inflammatory cytokines (interleukin-6, interleukin1 beta, and tumor necrosis factor-alpha), neonatal brain white matter lesions, and cerebral palsy. Am J Obstet Gynecol. 1997;177(1):1926.

20 Moscuzza F, Belcari F, Nardini V, Bartoli A, Domenici C, Cuttano A, et al. Correlation between placental histopathology and fetal/neonatal outcome: chorioamnionitis and funisitis are associated to intraventricular haemorrage and retinopathy of prematurity in preterm newborns. Gynecol Endocrinol. 2011;27(5): $319-23$.
21 Martinez E, Figueroa R, Garry D, Visintainer P, Patel K, Verma U, et al. Elevated amniotic fluid interleukin- 6 as a predictor of neonatal periventricular leukomalacia and intraventricular hemorrhage. J Matern-Fetal Investig. 1998;8(3):101-7.

22 Kasper DC, Mechtler TP, Bohm J, Petricevic L, Gleiss A, Spergser J, et al. utero exposure to Ureaplasma spp. is associated with increased rate of bronchopulmonary dysplasia and intraventricular hemorrhage in preterm infants. J Perinat Med. 2011;39(3):331-6.In

23 Rodriguez-Trujillo A, Cobo T, Vives I, Bosch J, Kacerovsky M, Posadas DE, et al. Gestational age is more important for short-term neonatal outcome than microbial invasion of the amniotic cavity or intra-amniotic inflammation in preterm prelabor rupture of membranes. Acta Obstet Gynecol Scand. 2016; 95(8):926-33.

24 Cobo T, Vives I, Rodríguez-Trujillo A, Murillo C, Ángeles MA, Bosch J, et al. Impact of microbial invasion of amniotic cavity and the type of microorganisms on short-term neonatal outcome in women with preterm labor and intact membranes. Acta Obstet Gynecol Scand. 2017;96(5):570-9.

25 Takakura S, Kodama Y, Yamashita R, Kino E, Kawano N, Tomimori K, et al. Characteristics and influence of mycoplasma/Ureaplasma cultures in amniotic fluid on perinatal outcomes. J Obstet Gynaecol Res. 2019.

26 Berger A, Witt A, Haiden N, Kaider A, Klebermasz $\mathrm{K}$, Fuiko R, et al. Intrauterine infection with Ureaplasma species is associated with adverse neuromotor outcome at 1 and 2 years adjusted age in preterm infants. J Perinat Med. 2009;37(1):72-8.

27 Fonseca LT, Silveira RC, Procianoy RS. Ureaplasma bacteremia in very low birth weight infants in Brazil. Pediatr Infect Dis J. 2011; 30(12):1052-5.

28 Kirchner L, Helmer H, Heinze G, Wald M, Brunbauer $\mathrm{M}$, Weninger $\mathrm{M}$, et al. Amnionitis with Ureaplasma urealyticum or other microbes leads to increased morbidity and prolonged hospitalization in very low birth weight infants. Eur J Obstet Gynecol Reprod Biol. 2007;134(1):44-50.

29 Waites KB, Crouse DT, Cassell GH. Systemic neonatal infection due to Ureaplasma urealyticum. Clin Infect Dis. 1993;17(Suppl 1): S131-5.
Ureaplasma-Driven Neonatal

Neuroinflammation
Neonatology 2020;117:665-672

DOI: $10.1159 / 000512019$ 
30 Normann E, Lacaze-Masmonteil T, Eaton F, Schwendimann L, Gressens P, Thébaud B. A novel mouse model of Ureaplasma-induced perinatal inflammation: effects on lung and brain injury. Pediatr Res. 2009;65(4):430-6.

31 Kelleher MA, Liu Z, Wang X, Kroenke CD, Houser LA, Dozier BL, et al. Beyond the uterine environment: a nonhuman primate model to investigate maternal-fetal and neonatal outcomes following chronic intrauterine infection. Pediatr Res. 2017;82(2):244-52.

32 Senthamaraikannan P, Presicce P, Rueda CM, Maneenil G, Schmidt AF, Miller LA, et al. Intra-amniotic Ureaplasma parvum-induced maternal and fetal inflammation and immune responses in rhesus macaques. J Infect Dis. 2016;214(10):1597-604.

33 Gussenhoven R, Ophelders DRMG, Kemp MW, Payne MS, Spiller OB, Beeton ML, et al. The paradoxical effects of chronic intra-amniotic Ureaplasma parvum exposure on ovine fetal brain development. Dev Neurosci. 2017; 39(6):472-86.

34 Silwedel C, Speer CP, Haarmann A, Fehrholz $\mathrm{M}$, Claus H, Schlegel N, et al. Ureaplasma species modulate cytokine and chemokine responses in human brain microvascular endothelial cells. Int J Mol Sci. 2019;20(14):3583.

35 Silwedel C, Speer CP, Haarmann A, Fehrholz $\mathrm{M}$, Claus H, Schlegel N, et al. Ureaplasma species modulate cell adhesion molecules and growth factors in human brain microvascular endothelial cells. Cytokine. 2019;121:154737.

36 Silwedel C, Haarmann A, Fehrholz M, Claus $\mathrm{H}$, Speer CP, Glaser K. More than just inflammation: Ureaplasma species induce apoptosis in human brain microvascular endothelial cells. J Neuroinflammation. 2019;16(1):38.

37 Silwedel C, Speer CP, Haarmann A, Fehrholz $\mathrm{M}$, Claus $\mathrm{H}$, Buttmann $\mathrm{M}$, et al. Novel insights into neuroinflammation: bacterial lipopolysaccharide, tumor necrosis factor alpha, and Ureaplasma species differentially modulate atypical chemokine receptor 3 responses in human brain microvascular endothelial cells. J Neuroinflammation. 2018;15(1):156.

38 Cruz-Orengo L, Holman DW, Dorsey D, Zhou L, Zhang P, Wright M, et al. CXCR7 influences leukocyte entry into the CNS parenchyma by controlling abluminal CXCL12 abundance during autoimmunity. J Exp Med. 2011;208(2):327-39.

39 Wevers NR, de Vries HE. Morphogens and blood-brain barrier function in health and disease. Tissue Barriers. 2016;4(1):e1090524.

40 Rodrigues SF, Granger DN. Blood cells and endothelial barrier function. Tissue Barriers. 2015;3(1-2):e978720.

41 Moll NM, Cossoy MB, Fisher E, Staugaitis SM, Tucky BH, Rietsch AM, et al. Imaging correlates of leukocyte accumulation and CXCR4/CXCL12 in multiple sclerosis. Arch Neurol. 2009;66(1):44-53.
42 Huang J, Li Y, Tang Y, Tang G, Yang GY, Wang Y. CXCR4 antagonist AMD3100 protects blood-brain barrier integrity and reduces inflammatory response after focal ischemia in mice. Stroke. 2013;44(1):190-7.

43 Forrester JV, McMenamin PG, Dando SJ. CNS infection and immune privilege. Nat Rev Neurosci. 2018;19(11):655-71.

44 Bielaszewska M, Rüter C, Kunsmann L, Greune L, Bauwens A, Zhang W, et al. Enterohemorrhagic Escherichia coli hemolysin employs outer membrane vesicles to target mitochondria and cause endothelial and epithelial apoptosis. PLoS Pathog. 2013;9(12):e1003797.

45 Zhang T, Bae D, Wang C. Listeriolysin O mediates cytotoxicity against human brain microvascular endothelial cells. FEMS Microbiol Lett. 2015;362(12):fnv084.

46 Risau W, Wolburg H. Development of the blood-brain barrier. Trends Neurosci. 1990; 13(5): 174-8.

47 Chau A, Markley JC, Juang J, Tsen LC. Cytokines in the perinatal period - Part II. Int J Obstet Anesth. 2016;26:48-58.

48 Shaalan A, Carpenter G, Proctor G. Caspases are key regulators of inflammatory and innate immune responses mediated by TLR3 in vivo. Mol Immunol. 2018;94:190-9.

49 Moss TJ, Knox CL, Kallapur SG, Nitsos I, Theodoropoulos C, Newnham JP, et al. Experimental amniotic fluid infection in sheep: effects of Ureaplasma parvum serovars 3 and 6 on preterm or term fetal sheep. Am J Obstet Gynecol. 2008;198(1):122-8.

50 Viscardi R, Manimtim W, He JR, Hasday JD, Sun CC, Joyce B, et al. Disordered pulmonary myofibroblast distribution and elastin expression in preterm infants with Ureaplasma urealyticum pneumonitis. Pediatr Dev Pathol. 2006;9(2):143-51.

51 Viscardi RM, Manimtim WM, Sun CC, Duffy L, Cassell GH. Lung pathology in premature infants with Ureaplasma urealyticum infection. Pediatr Dev Pathol. 2002;5(2):141-50.

52 Snyder CC, Wolfe KB, Gisslen T, Knox CL, Kemp MW, Kramer BW, et al. Modulation of lipopolysaccharide-induced chorioamnionitis by Ureaplasma parvum in sheep. Am J Obstet Gynecol. 2013;208(5):399-8.

53 Glaser K, Silwedel C, Fehrholz M, Henrich B, Waaga-Gasser AM, Claus H, et al. Ureaplasma isolates stimulate pro-inflammatory CC chemokines and matrix metalloproteinase- 9 in neonatal and adult monocytes. PloS One. 2018;13(3):e0194514.

54 Glaser K, Silwedel C, Fehrholz M, WaagaGasser AM, Henrich B, Claus H, et al. Ureaplasma species differentially modulate proand anti-inflammatory cytokine responses in newborn and adult human monocytes pushing the state toward pro-inflammation. Front Cell Infect Microbiol. 2017;7:484.
55 Glaser K, Silwedel C, Waaga-Gasser AM, Henrich B, Fehrholz M, Claus H, et al. Ureaplasma isolates differentially modulate growth factors and cell adhesion molecules in human neonatal and adult monocytes. Cytokine. 2018;105:45-8.

56 Kallapur SG, Kramer BW, Knox CL, Berry CA, Collins JJ, Kemp MW, et al. Chronic fetal exposure to Ureaplasma parvum suppresses innate immune responses in sheep. J Immunol. 2011;187(5):2688-95.

57 Stowe AM, Wacker BK, Cravens PD, Perfater JL, Li MK, Hu R, et al. CCL2 upregulation triggers hypoxic preconditioning-induced protection from stroke. J Neuroinflammation. 2012;9:33

58 Li L, McBride DW, Doycheva D, Dixon BJ, Krafft PR, Zhang JH, et al. G-CSF attenuates neuroinflammation and stabilizes the bloodbrain barrier via the PI3K/Akt/GSK-3 $\beta$ signaling pathway following neonatal hypoxiaischemia in rats. Exp Neurol. 2015;272:13544.

59 Reyes TM, Coe CL. The proinflammatory cytokine network: interactions in the CNS and blood of rhesus monkeys. Am J Physiol. 1998; 274(1 Pt 2):R139-44.

60 Cardoso FL, Herz J, Fernandes A, Rocha J, Sepodes B, Brito MA, et al. Systemic inflammation in early neonatal mice induces transient and lasting neurodegenerative effects. J Neuroinflammation. 2015;12:82

61 Silwedel C, Förster C. Differential susceptibility of cerebral and cerebellar murine brain microvascular endothelial cells to loss of barrier properties in response to inflammatory stimuli. J Neuroimmunol. 2006;179(1-2):37-45.

62 Manimtim WM, Hasday JD, Hester L, Fairchild KD, Lovchik JC, Viscardi RM. Ureaplasma urealyticum modulates endotoxin-induced cytokine release by human monocytes derived from preterm and term newborns and adults. Infect Immun. 2001;69(6):3906-15.

63 Goldenberg RL, Hauth JC, Andrews WW. Intrauterine infection and preterm delivery. $\mathrm{N}$ Engl J Med. 2000;342(20):1500-7.

64 López-Collazo E, del Fresno C. Pathophysiology of endotoxin tolerance: mechanisms and clinical consequences. Crit Care. 2013;17(6): 242.

65 Resch B, Gutmann C, Reiterer F, Luxner J, Urlesberger B. Neonatal Ureaplasma urealyticum colonization increases pulmonary and cerebral morbidity despite treatment with macrolide antibiotics. Infection. 2016;44(3): 323-7.

66 Kenyon S, Pike K, Jones DR, Brocklehurst P, Marlow N, Salt A, et al. Childhood outcomes after prescription of antibiotics to pregnant women with spontaneous preterm labour: 7-year follow-up of the ORACLE II trial. Lancet. 2008;372(9646):1319-27. 